\title{
International Trade of Chilean and Tasmanian Salmon and the Governmental Human Resource Policy enabling its Expansion
}

\author{
Arslan Naru * \\ Faran Shoaib **
}

\begin{abstract}
International trade policy theorists have repeatedly focused their works on actors developing or implementing policies, rather than the actual policies themselves. Dani Rodrik, Chalmers Johnson and Peter Evans are amongst those renowned international trade and industrialization scholars who dedicated most of their research to human resource development in countries that delivered miraculous economic growth. Chile may be considered one of those miraculous states, in part due to the development of its salmon fishing industry. Tasmania, another southern hemisphere salmon producing region, has also procure a State-guided sectorial development. Both face common attributes and challenges. On one hand, Chile and Tasmania salmon development is highly explained due to the existence of a bureaucratic regime highly supportive of human capital development in the new sector. On the other hand, still both face challenges to find the right balance between profitability and environmental sustenance. Chile has shown record export growth, but it has raised questions on sanitary management; while Tasmania has enforced strict environmental compliance, it has hardly earned anything from exports of Salmon.
\end{abstract}

Keywords: Chile, Tasmania, salmon, human resources development, development policies.

\section{Resumen}

Los teóricos de la política económica internacional han focalizado de forma permanente sus trabajos en los actores que desarrollan o implementan políticas, más que las propias políticas. Dani Rodrik, Chalmers Johnson, y Peter Evans están entre los académicos del comercio internacional y la industrialización que han dedicado sus investigaciones al análisis del desarrollo de los recursos humanos en países que han logrado crecimientos económicos milagrosos. Chile puede ser considerado entre estos países, en parte por el desarrollo de su industria salmonera. Tasmania, otra región del hemisferio sur productora de salmón, también ha tenido un desarrollo del sector guiado por el Estado. Ambos comparten atributos y desafíos. Por una parte, el crecimiento de la industria del salmón en Chile y Tasmania es altamente explicado por la existencia de regímenes burocráticos que han apoyado el desarrollo del capital humano en el sector. Por otra, los dos enfrentan el desafío de balancear la rentabilidad y el manejo sanitario. Mientras Chile ha presentado un crecimiento record de las exportaciones, ha levantado cuestionamientos respecto del manejo sanitario de los cultivos; y Tasmania que ha aplicado regulaciones ambientales más estrictas, no ha tenido réditos económicos de la exportación de salmón.

Palabras claves: Chile, Tasmania, salmón, desarrollo de recursos humanos, políticas de desarrollo.

*Assistant Professor of Human Resources and Comparative Employee Relations, at FAST School of Management, National University of Computer and Emerging Sciences, Lahore Pakistan. Email address: arslan.shoaib@nu.edu.pk. Received: March 20th 2019; accepted: April, 17th 2019.

** Researcher currently based in Canberra, Australia. He is also affiliated with Centre for Public Policy \& Governance at Forman Christian College. Email: faranshoaib@hotmail.com 
Arslan Naru, Faran Shoaib

International Trade of Chilean and Tasmanian Salmon and the Governmental Human Resource Policy enabling its Expansion

\section{Introduction}

Salmon farming is a USD $\$ 15$ billion per annum industry that has created 0.13 million jobs in different countries (ISFA, 2016). 2.5 million tons of this fish is produced in farms each year according to the International Salmon Farmers Association. In 2017, Chile produced 0.79 million tons of Salmon, whereas Tasmania, Australia produced 0.05 million Tons (SalmonChile; TAS Government, 2017). Chile's salmon farms created 60,000 jobs whereas 5,200 jobs were created in Tasmania directly or indirectly. According to production estimates above, Chile produces $31 \%$ of the global farmed salmon but employs $45 \%$ of the global workforce engaged in salmon farming (SalmonChile). On the other hand, Tasmania produces only $0.02 \%$ of global production but employs $0.04 \%$ of the global human resources operating salmon farms (TAS Government, 2017). These percentage figures point to the fact that the much larger Chilean industry is labor intensive. This paper does not compare these two states' salmon business based on absolute terms because Chile's production is almost 16 times larger than Tasmania. This paper compares how two different Governments initiated an altogether new industry by investing itself or by supporting human development through research on production techniques, hatcheries, vaccines, fish feed and various other aspects of aquaculture.

Governments in both Chile and Tasmania started from scratch. Chile's National Fishing Agency (Servicio Nacional de Pesca y Acuicultura) imported 40 million eggs from Japan in 1969 with the help of JICA (UNCTAD, 2006). Fifteen years after that, Tasmanian Government brought in fertilized eggs from Nova Scotia, Canada in 1984 to kick start an industry that now brings more than USD \$500 million worth of sales revenue every year (TAS Government, 2017). Importing eggs would have had no use if governments in these countries had not embarked on training of personnel needed to get those eggs to grow into marketable fish. The primary focus of these Governments was Human Resource Development.

People are what make businesses grow and so early investment in people is now bringing profits worth millions in Tasmania and billions in Chile. Chile has delivered an economic miracle by getting into a completely new salmon industry and becoming its second largest exporter, all in a matter of a few decades. However, when Chile or even Tasmania started on an unexplored road of an unknown salmon farming industry; they needed people who could deliver a myriad of different services. People were needed to control fresh water environments in hatcheries; produce optimum fish meal; design durable sea pens; dive under water to clean them; conduct research on vaccines/antibiotics; conduct controlled breeding for genetic superiority; manage/harvest fish; prepare fillets; transport fish; and market the product in far off countries. None of these jobs could be done because trained human resource simply did not exist at the outset. Government institutions had to be proactive in taking the lead to initiate the development of a capable human resource.

Chilean government institutions helped to build the human resource for four sections of the industry; hatcheries which employ $15 \%$ of the industry's labor force, sea pens which employ $33 \%$ of people for growth and harvest, product processing centers which employ $50 \%$ of workers for cutting of fillets or packaging, and finally scientists which make up a small percentage but do the most important work of disease resistance or selective breeding (Rainbird \& Ramirez, 2012). These percentages are close to the salmonid workforce division in Tasmania, where $5 \%$ work in hatcheries, $38 \%$ on sea pens, $39 \%$ on packaging and 18\% in management (TSIC, 2017). The most obvious difference between Chile and Tasmania is that of greater staff allocation to management, HR and administration. Rainbird \& Ramirez (2012) explain how Chile was able to upgrade the human resource of its southern regions through 
participation in global value chains of international salmon trade. They also argue that it was government institutions that gradually helped build the work force needed for smooth operation of an entirely new industry. This was certainly achieved in close coordination with actual salmon farming companies working on the ground. Two most prominent government institutes credited with the development of the salmon industry are CORFO (Corporación de Fomento para la Producción) and Fundación Chile. It must be noted here that although Fundación Chile is not a strictly government institution, it was founded by the Government in collaboration with few private investors. These institutions subsidized the learning, human development and training that was needed to create local substitutes for imported eggs/fish meal and create vaccines that could prevent disease outbreaks.

Specialized institutes directed at human development and training were created by the Chilean Government to diversify into previously unexplored business of salmon farming. A National Service for training and employment called SENCE (Servicio Nacional de Capacitación y Empleo) was setup under the Ministry of Labor, which adopted a tax rebate system to attract farming companies to trainings (Rainbird $\&$ Ramirez, 2012). The system of training tax rebate ${ }^{1}$, introduced in 1976, was a very innovative incentive of Chilean Government's Human Resource development policy (Ministry of Social Development, Chile, 2015) (Sehnbruch, 2006). Farming companies could claim a small percentage of tax rebate if they had trained their employees. This encouraged rapid capacity building of salmon farming industry in the 1990s. Foreign donors such as JICA also supported Chilean Government in creation of human development institutions, one example of which is a training organization called Fundación Chinquibue (Rainbird \& Ramirez, 2012). Another Chilean training institute of prominence is INTESAL (Instituto Tecnologico del Salmón), which was created by SalmonChile in 1994, an association of Salmon Farmers (UNCTAD, 2006). Although, INTESAL's trainings are not directly coordinated by the Government, it keeps a close coordination with the organization and industrial association.

Tasmanian Government started funding a not-for-profit institute called Seafood \& Maritime Training (SMT) in 2015 under a 'Seafood pledge". This pledge promised two million Australian dollars for skills and safety training in seafood industry and was extended in 2017 (Hodgman, 2017). SMT, the organization receiving the governmental funding, had earlier built the capacity of seafood Workforce in Tasmania by training 6,431 people between 2010-2015; through 33 courses on finfish husbandry, food safety, fish health, and quality assurance etc. (TSIC, 2017).

\section{Differences of Salmon Industry in Chile and Tasmania}

Growth of salmon industry in Chile was always oriented to exports, particularly to developed nations such as Japan and United States with high purchasing power (Hosono, Iiizuka, \& Katz, 2017; Rodrik, 2008). Chilean salmon produced in four southern regions: La Araucanía, Los Lagos, Aysen and Magallanes is exported to 70 different countries around the world (ISFA, 2016). Tasmanian salmon on the other hand is mostly oriented to Australia domestic markets, which by themselves have high purchasing power, leaving only 7\% of the product for exports (Buxton \& Jungalwalla, 2010).

A technical difference between the two countries' salmon farming is that Tasmania has warmer and more temperate waters, unlike Chile, Norway, Faroe Islands or most other salmon producing regions. The implication of producing salmon in relatively warmer waters is that it can grow to full size much quicker,

1 This tax rebate or credit is called "Franquicia Tributaria de Capacitación." It is offered by Chilean Government's Servicio Nacional de Capacitación y Empleo, under the Ministerio de Trabajo y Previsión Social. 
Arslan Naru, Faran Shoaib

International Trade of Chilean and Tasmanian Salmon and the Governmental Human Resource Policy enabling its Expansion

but the premature growth of the fish makes it more susceptible to diseases. CSIRO, an Australia Federal Government organization conducts research on ways to delay this maturation and keep Tasmanian salmon's quality at par with Chile and rest of the world ${ }^{2}$. The first phase of salmon growth, the hatching of eggs, was also initially conducted in different manners in the two countries, although Chilean salmon industry had grown large enough in 2003 to afford overland hatching facilities, artificially creating ideal growing condition, the real start of hatcheries was on Lake Llanquihue (Soluri, 2011). The ownership of salmon farms in Chile is mostly held by private firms or large international firms, and these farms are spread out on a much larger geographic area. They can no longer be dependent on hatcheries around Lake Llanquihue and so have expanded into their own over land hatcheries. The hatchery in Tasmania on the other hand is mutually owned by most major commercial salmon farming companies. This hatchery started running at fully capacity in late 1980s producing 1 million smolts. A prominent feature of this hatchery known as Salmon Enterprises of Tasmania (SALTAS) is that it sets aside $25 \%$ of its revenue for research and development (SALTAS, 1990).

There is also a substantial difference in the work environment of two countries. Chile has created more jobs in the industry than any other salmon farming country, however the employee rights and working conditions have been a subject of some criticism. Collective bargaining and organization of unions are relatively weak in the labor-intensive industry of Chile, which at times results in difficult labor conditions (Rainbird \& Ramirez, 2012). The power over labor related issues is concentrated in upper echelons. This is related to Chilean neoliberalist economic policies (Phyne, 2010). John Phyne attributes the differences in allocation of work rights between Chile and countries like Norway, to differences in economic orientation. He argues that social democratic economic outlook of Norway allowed greater freedom of collective bargaining. He explains that the return of labor party in Norway after the end of war in 1945, brought about by organized labor unions, laid a strong foundation of collective bargaining in Norwegian workforce. In contrast, Chile started carrying forward Pinochet's neoliberalism in 1974, which puts business expansion over and above any distribution of gains or sharing or rights between all members of labor community. Soluri (2011) argues that since labor organizing was forbidden in Pinochet's repressive regime, the salmon industry workforce was never able to build a culture of collective bargaining. Rainbird \& Ramirez (2012) explain that despite Norwegian salmon firms' foreign direct investment in Chile, they did not transfer their employee friendly human resource policies of unionization and participative management to Chile.

Low job security in Chile has also been a point of concern. The outbreak of Infectious Salmon Anaemia (ISA) between 2007 and 2009 not only killed 65\% of the salmon fish in Chilean farms, but also eliminated $40 \%$ of jobs, rendering many Chileans completely unemployed (SalmonChile). Epidemic and environmental disasters such as this have continued to eliminate jobs in Chile. In April 2016, countless dead fish washed ashore Chiloé, a Chilean island, prompting the Government to immediately halt any fishing by locals rendering them, so they were unable to earn their livelihoods (Thomas, 2018). Locals blamed the crisis on unsanitary dumping of dead fish by salmon farmers and launched a long protest.

\footnotetext{
2 A high quality product is one that has minimum or no contaminants. (Hites, et al., 2004) analyzed contaminants especially the polychlorinated biphenyls (PCB) in salmon exported by Chile and various northern hemisphere States such as Scotland, Faroe Islands, Norway, Canada, etc. and revealed that lowest PCBs were found in Chilean salmon pointing to healthier higher quality product. No comparison of PCB contamination can be done between Chilean and Tasmanian salmon because of the lack of studies on contamination in Tasmanian salmon. However, a comparison might be possible in the future as the report on finfish aquaculture submitted to the Parliament of Australia specifically states the need for having tests of PCBs and other contaminants in Tasmanian salmon; to gauge whether Tasmanian salmon's quality is at par with Chile's (Environment and Communications References Committee, The Senate of Australia, 2015).
} 
Considering Tasmania, currently the salmon industry employs 5,740 people, of which $36 \%$ are directly involved in salmonid farming (Carson, et al., 2016) and 67\% work on a full time basis (TSIC, 2017). In contrast to Tasmanian workforce, considerable people in Chilean salmon industry work on per piece basis, getting limited payments based on the number of fillets that they were able to cut out while standing in low temperatures (Soluri, 2011). Soluri was also critical of mortalities of deep-sea divers in Chile who died on job while cleaning sea pens.

Despite the differences discussed in this section, the salmon industries of both Chile and Tasmania had remarkable similarities in their growth trajectory. This was due to similar government policies in both countries that aimed to develop the human capital needed to establish and operate a highly profitable industry. The government support in these countries is individually discussed in the sections below.

\section{Government support in Chile}

The Government of Chile supported salmon farmers at every stage, starting from the importation of eggs to promotion and marketing of prepared salmon in foreign countries through representatives of Fundación Chile (UNCTAD, 2006). The promotion was done through 56 international offices of ProChile, an organization of the Chilean Ministry of Foreign Affairs. According to UNCTAD, Government's efforts in human development created people capable of delivering a host of services, such as building net pens and providing maintenance/pathological services etc. The Chilean Government also helped salmon exporters get quality assurance certificates from HACCP or Food and Drug administration of the United States Government (UNCTAD, 2006).

The most substantial supportive role played by Chilean Government was to become a pioneer itself. When starting an unknown industry in the country, it is very natural to expect that local investors would be reluctant to put their money into a business that they know very little of. To break this hesitation, the Government of Chile not only created knowledge related to various aspects of salmon farming but also became the first investor itself. Fundación Chile decided to setup salmon farming companies itself to allow local investors to imitate the success later. Fundación Chile is a non-profit organization that was mutually founded by both government and private investors. The Government through Fundación Chile established the first salmon farming business in 1982 for demonstrative purposes. This demonstration or prototype broke the reluctance of hesitant investors (UNCTAD, 2006).

Once the industry was established and operational, the Government helped the sector grow by creating sanitary regulations, funding research on disease resistance and allocating suitable area for setting up of new sea pens. Fundación Chile also helped exporters with vacuum packaging of salmon to extend its shelf life and increase the sales of an otherwise perishable commodity.

Due to the distance of Chile from most export markets such as European Union, Japan and US, Chile's export was mostly limited to frozen fillets and not live fish. To overcome this concern, CORFO through one of its organizations called FONTEC (Fondo Nacional de Desarrollo Tecnológico y Productivo) ${ }^{3}$ paid for the designing of ships and well boats that can transport live fish (UNCTAD, 2006).

\footnotetext{
${ }^{3}$ Now, Innova Chile
} 
Arslan Naru, Faran Shoaib

International Trade of Chilean and Tasmanian Salmon and the Governmental Human Resource Policy enabling its Expansion

\section{Government Support in Tasmania}

Tasmania's salmon industry growth plan specifically states full support from the Government, the elected premier and his political party, to salmon farming (TAS Government, 2017). However, since water resources are collectively owned by entire community of Tasmania, community's criticism of pollution by salmon farmers has legal standing and electoral repercussions. In 2016, a small community of Chilean citizens in the island of Chiloé also asserted their power to criticize alleged pollution by salmon farmers, however that only happened after Millions of dead fish were washed ashore on that island. In comparison to Chile, Tasmania is considerably conservative in expansion of this industry. A very large proportion of Tasmania's coastal areas are declared as "No Grow Zones" for salmon farming, limiting farming areas to Tamar River in the north, Macquarie harbor in the west and areas south of Hobart. This is in response to local citizens' concerns of having large farms on their coastal horizon. Tasmanian Government has adopted significant measures towards environmental compliance. Examples include penalties for farming out of designated areas and formation of salmon farming monitoring unit under Environmental Protection Authority.

The Federal Government of Australia also supports Tasmania's industry through its Fisheries Research and Development Corporation (FRDC), operating under the Federal Minister of Agriculture, Fisheries and Forestry. This Federal department helped salmon farmers develop more durable sea pens that seals could not breakthrough in their attempt at eating farmed salmon (Buxton \& Jungalwalla, 2010). FRDC designed stiffer cages and nets for that purpose. Like Tasmania, Chile also invested in evolution of its sea pens, gradually increasing its pen sizes to 20 meters wide, made of durable materials such as high impact plastic or aluminum (UNCTAD, 2006). The development of durable pens is also essential from environmental standpoint of ecosystem sustenance as Stokstad (2002) and Sepúlveda, Arismendi, Soto, Jara, \& Farias (2013) argue that farmed salmon escaped from pens are more aggressive due to selective breeding, and so consume the food of wild salmon, lowering wild salmon's chances of survival. Escaped salmon can also transfer diseases from farmed to wild populations of the fish. The residents of Chiloé Island alleged that the dumping of sick or dead salmon by Chilean farmers resulted in death of millions of fish that were washed ashore (Thomas, 2018).

FRDC is the embodiment of Federal Australian Government's co-funded partnership with the fishing sector to undertake research. The Tasmanian Government also pays FRDC to undertake research on different aspects of salmonid farming in the state. (DPIPWE, 2009). Another Federal agency of Australian Government called Commonwealth Scientific and Industrial Research Organization (CSIRO) conducted selective breeding from 180 different salmon families to create superior generations of salmon that were more capable of resisting diseases and exhibited better growth. Chilean Government through Fundación Chile also benefited from the work of Norwegian breeders who developed strains of highquality Salmon with increased body weight, better stress tolerance and improved disease resistance (Soluri, 2011).

\section{Governments' Engagement of Universities and Academic Experts for Knowledge Creation}

Chilean Government's foremost success in salmon business was that of knowledge creation. Knowledge of how to operate hatcheries, how to manage sea pens, how to resist diseases, and how to market and sell value added products for better profitability. The proactive role of Fundación Chile and CORFO in knowledge creation and diffusion is praised by (Hosono, Iiizuka, \& Katz, 2017). Chilean Government's 
ability to create knowledge was tested when a disease outbreak in 2007 damaged large number of fish, or when environmental malpractices forced the Government to revise the Aquaculture Law in 2011 and create new regulatory institutions to implement it (Alvial, et al., 2012). Tasmanian government also had to create knowledge on disease prevention when Amoebic Gill Disease repeatedly broke out in warmer months or when Tasmanian community raised concerns about potential environmental abuse by salmon farmers (Bagley, 2006). In both countries, it was academics and universities that helped the Government create most advanced knowledge on how to cope and adapt.

Both Chile and Tasmanian Governments utilized academic experts to study the environmental sustainability of salmon farming. In Chile, University of Concepcion was funded by the Government of Chile to create a system of monitoring and cleaning sea beds under the pens through remote sensing technology (UNCTAD, 2006). Tasmanian Government also engaged experts from Institute of Marine and Antarctic Studies at University of Tasmania to study accumulation of bio mass and feed waste on the sea bed of Macquarie harbor, directly under the pens (IMAS, 2016). Tasmanian State Government has created a joint venture with the academic world by creating Tasmanian Aquaculture and Fisheries Institute (TAFI), within the University of Tasmania.

There are multiple examples of Government academic collaboration that helped the salmon industry grow. Government of Chile financed University of Chile to study the impacts and risks of well boats in transporting live fish to export destinations. Similarly, University of Concepcion worked with CORFO to develop a vaccine against a salmon disease called Infectious Pancreatic Necrosis. Yet another example of academia's contribution is the work of University of Valparaiso in formulation of a cheaper feed for fish made of vegetable derived ingredients. Austral University in Valdivia and Los Lagos University offered degree programs in aquaculture to help develop qualified labor force for the salmon farming industry (UNCTAD, 2006).

Apart from the academia, Governments in both counties also funded the development of human resources in disease resistance and feed production. These two most important aspects of salmon farming were directly addressed by both Governments as briefly discussed in the following sections.

\section{Building Human Capital for Technical Work of Disease Prevention}

Tasmanian Government funded two organizations capable of conducting research on Amoebic Gill Disease, called Institute of Marine \& Antarctic Studies (IMAS) and Aquatic Animal Health and Vaccines Centre, which also study various other scientific aspects of salmon farming. IMAS for instance conducted a large-scale study of oxygen levels in Macquarie harbor as its depletion can cause death of fish (IMAS, 2016). The Centre for Aquatic Animal Health and Vaccines is operated by Department of Primary Industries, Parks, Water and Environment (DPIPWE), a department of Tasmanian Government. This state government department works in close coordination with Tasmanian Salmon Growers Association. The Centre provides highly technical services to salmon farmers such as diagnostic testing of fish viruses. This center has also developed four different types of vaccines for Vibriosis and other salmon diseases. These vaccines were developed between the years of 1986 and 2013, pointing to its sustained research effort.

The outbreak of Infectious Salmon Anaemia (ISA) reduced Chile's production from 0.4 million tons in 2005 to only 0.1 million tons in 2010 (Asche, Hansen, Tveteras, \& Sigbjørntveterås, 2009). Asche et al criticize the reactive role of Chilean government toward the ISA disease raising questions on lack of preemptive measures when industry practitioners knew of the devastating effects of this epidemic well before 
Arslan Naru, Faran Shoaib

International Trade of Chilean and Tasmanian Salmon and the Governmental Human Resource Policy enabling its Expansion

it struck. Chile's losses have a clear lesson for other nations aspiring to walk in Chile or Tasmania's footsteps to develop an aquaculture industry. This lesson is about investing in fish pathologists and vaccine researchers right at the start. Building human resource for scientific management of diseases is a simultaneous task that starts at the outset of industry's development.

\section{Building Human Resource for an Ancillary Industry of Feed Production}

Feed constitutes about half of the business expenditure in salmon farming and European firms have primarily dominated this industry (Rainbird \& Ramirez, 2012). As the industry grew in both Chile and Tasmania, it became evident that to cut cost of production, a local substitute must be developed to minimize raw material importation costs. Like Chile, Tasmanian fish feed supply was also originally dominated by foreign multinationals but using Tasmanian ingredients in the local production of that supply became a policy choice that encouraged local growth of this ancillary sector. Fisheries Research and Development Corporation (FRDC) of the Federal Government of Australia initiated a Diet Development Subprogram to evaluate the ingredients of fish feed and develop an efficient high energy feed that could produce heavier fish meat for every $\mathrm{kg}$ of feed consumed (Buxton \& Jungalwalla, 2010).

\section{Conclusion}

This paper puts together specific government policies that helped build a similar industry in two vastly different countries of the southern hemisphere. It also underscores the benefits of strong government support towards human resource development thereby directly contributing to the creation and growth of new industries. The paper distills pertinent examples of public private partnership to display how an industry can be built from scratch by governments that are developmental in their outlook instead of being predatory. The Governments of Chile and Tasmania were completely embedded in salmon industry, looking after every minor aspect ranging from designing of sea pens to discovery of vaccines. The human resource development initiatives taken by governments and the subsequent industry success is also supported by other similar studies (Metcalfe \& Rees, 2005; Esichaikul \& Baum, 1998). Government support of human resource development yields positive results and advances the economy. While being embedded, these governments were also autonomous by not controlling the industry or by not extracting any benefits from the industry in exchange. These governments comply with Peter Evans' economic development theory of "embedded autonomy" (Evans, 1995). Dani Rodrik, a preacher of proactive government role in coordinating the industry and minimizing rent seeking, depicts Chilean success in salmon farming as a success of the Government (Rodrik, 2007).

This paper reveals striking similarities between supportive initiatives of two completely different countries. Both countries emphasized and encouraged the development of the right workforce through trainings. Human capital development was the most fruitful government policy that helped establish highly profitable salmon businesses in Chile and Tasmania. Through Human Resource Development policies, Government of Tasmania helped to create more than 5,000 jobs whereas Chile provided work opportunities to over 60,000 people. Thousands of jobs were created, and billions of dollars were made as a result of these policies. 
Latin American Journal of Trade Policy 3 (2019) - Universidad de Chile

\section{References}

Alvial, A., Kibenge, F., Forster, J., Burgos, J. M., Ibarra, R., \& St-Hilaire, S. (2012). The recovery of the Chilean Salmon Industry. Puerto Montt: World Bank.

Asche, F., Guttormsen, A. G., \& Tveteras, R. (2008). Aquaculture-Opportunities and Challenges Special Issue Introduction. Marine Resource Economics, Vol. 23, No. 4, 395-400.

Asche, F., Hansen, H., Tveteras, R., \& Sigbjørntveterås. (2009). The Salmon Disease Crisis in Chile. Marine Resource Economics, Vol. 24, No. 4, 405-411.

Bagley, C. A. (2006). Potential risk factors of amoebic gill disease in Tasmanian Atlantic Salmon. Launceston: University of Tasmania.

Buxton, C., \& Jungalwalla, P. (2010). Salmon Aquaculture subprogram: Facilitation and Administration. Deakin, ACT: Fisheries Research and Development Corporation.

Carson, J., Morrison, R., Cornish, M. C., Wright, E. (Andrewartha, R., Klumpp, L., . . Wilkinson, R. (2016). The Australian Aquatic Animal Health and Vaccine Centre: first phase to establish Atlantic salmon biosecure fish facility capabilities and develop strategy for an Australian centre of excellence. Deakin, ACT: Fisheries Research and Development Corporation.

Coen, R. (2014). Selling Salmon to the World: The Export Market for Pacific Northwest Canned Salmon. The Pacific Northwest Quarterly, Vol. 105, No. 1, 23-31.

DeLoach, B. (1935). Important Factors Affecting the Marketing of Canned Salmon. American Marketing Journal, Vol. 2, No. 4, 253-264.

DPIPWE. (2009). The Tasmanian Salmon Industry. Hobart: Department of Primary Industries, Parks, Water and Environment, Government of Tasmania.

Environment and Communications References Committee, The Senate of Australia. (2015). Regulation of the fin-fish aquaculture industry in Tasmania. Canberra: Senate Printing Unit, Parliament House.

Esichaikul, R., \& Baum, T. (1998). The case for government involvement in human resource development: A study of the Thai hotel industry. Tourism Management, 359-370.

Evans, P. (1995). Embedded Autonomy: States \& Industrial Transformation. Princeton: Princeton Univ. Press.

Gereffi, G., \& Fernandez-Stark, K. (2011). Global V alue Chain Analysis: A Primer. Duke University Center on Globalization, Governance \& Competitiveness.

Hites, R. A., Foran, J. A., Carpenter, D. O., Hamilton, M. C., Knuth, B. A., \& Schwager, S. J. (2004). Global Assessment of Organic Contaminants in Farmed Salmon. Science, New Series, Vol. 303, No. 5655, 226-229.

Hodgman, W. (2017, 11 03). Backing our growing seafood industry. Retrieved from Premier of Tasmania: http://www.premier.tas.gov.au/releases/backing_our_growing_seafood_industry

Hosono, A., Iiizuka, M., \& Katz, J. (2017). Chile's Salmon Industry. Policy Challenges in Managing Public Goods. Research Policy 46, 898-899.

IMAS. (2016). Salmon Aquaculture: Monitoring and Management. Retrieved from Institute for Marine and Antarctic Studies (IMAS): http://www.imas.utas.edu.au/research/fisheries-andaquaculture/projects/projects/salmon-aquaculture-monitoring-and-management

ISFA. (2016). Salmon Farming: Sustaining Communities and Feeding the world. International Salmon Farmers Association.

Johnson, C. (1982). MITI and the Japanese Miracle. Stanford: Stanford University Press.

Metcalfe, B. D., \& Rees, C. J. (2005). Theorizing advances in international human resource development. Human Resource Development International, 449-465. 
Arslan Naru, Faran Shoaib

International Trade of Chilean and Tasmanian Salmon and the Governmental Human Resource Policy enabling its Expansion

Ministry of Social Development, Chile. (2015). Franquicia Tributaria de Capacitación. Santiago: Ministerio de Desarrollo Social, Gobierno de Chile.

Phelan, S. (2003). A Pacific Rim Approach to Salmon Management: Redefining the Role of pacific Salmon International Consensus. Environmental Law, Vol. 33, No. 1, 247-289.

Phyne, J. (2010). A Comparative Political Economy of Rural Capitalism: Salmon Aquaculture in Norway, Chile and Ireland. Acta Sociologica, Vol. 53, No. 2, 160-180.

Porter, M. E. (1990). The Competitive Advantage of Nations. New York: The Free Press.

Rainbird, H., \& Ramirez, P. (2012). Bringing social institutions into global value chain analysis: the case of salmon farming in Chile. Work, Employment \& Society, Vol. 26, No. 5, 789-805.

Rodrik, D. (2007). Industrial Policy for the Twenty-first Century. In D. Rodrik, One Economics Many Recipes: Globalization, Institutions, and Economic Growth (pp. 99-152). Oxfordshire: Princeton University Press.

Rodrik, D. (2008). Industrial Policy: Don't ask why, ask how. 1-29: Middle East Development Journal, Demo Issue.

Rodrik, D. (2014). Green industrial policy. Oxford Review of Economic Policy, Volume 30, 469-491.

SalmonChile. (n.d.). Chilean Salmon Industry Brief. Asociación de la Industria del Salmón de Chile.

SALTAS. (1990). Review of the Saltwater Salmonid Industry in Tasmania: Final Report. Salmon Enterprises of Tasmania P/L.

Sehnbruch, K. (2006). The Chilean Labor Market: A key to understanding Latin American labor makets. New York: Palgrave Macmillan.

Sepúlveda, M., Arismendi, I., Soto, D., Jara, F., \& Farias, F. (2013). Escaped farmed salmon and trout in Chile: incidence, impacts, and the need for an ecosystem view. Aquaculture Environment Interactions, Vol. 4, No. 3, 273-283.

Soluri, J. (2011). Something Fishy: Chile's Blue Revolution, Commodity Diseases, and the Problem ofSustainability. Latin American Research Review, Vol. 46, Special Issue: Contemporary Debates on Ecology, Society, and Culture in Latin America, 55-81.

Stiglitz, J. E., \& Uy, M. (1996). Financial Markets, Public Policy, and the East Asian Miracle. The World Bank Research Observer, Vol. 11, No. 2, 249-276.

Stokstad, E. (2002). Engineered Fish: Friend or Foe of the Environment? Science, New Series, Vol. 297, No. 5588, 1797-1799.

TAS Government. (2017). Sustainable Industry Growth Plan for the Salmon Industry. Hobart: Depar tment of Primary Industries, Parks, Water and Environment, Tasmanian Government.

Thomas, E. H. (2018). Crisis and catastrophe on Chiloé: Collective memory and the (re)framing of an environmental disaster. Cultural Dynamics, 30(3), 199-213.

TSIC. (2017). Seafood Industry Workforce Profile. Tasmanian Seafood Indutry Council.

UNCTAD. (2006). A case study of the Salmon Industry in Chile. Geneva: UNCTAD.

Wang, X., Olsen, L. M., Reitan, K. I., \& Olsen, Y. (2012). Discharge of nutrient wastes from salmon farms: environmental effects, and potential. Aquaculture Environment Interactions, Vol. 2, No. 3, 267-283.

Wood, L. (2002). Feed and Food Safety in the Farmed Atlantic Salmon Industry. Geography, Vol. 87, No. 2, 160-163.

Xie, J., \& Zhang, D. (2014). Imperfect Competition and Structural Changes in the US Salmon Import Market. Marine Resource Economics, Vol. 29, No. 4, 375-389. 